\title{
Correlates and determinants of Early Infant Diagnosis outcomes in North-Central Nigeria
}

Patrick Dakum ${ }^{1,2+}$, Monday Tola ${ }^{1 *+} \mathbb{0}$, Nta Iboro ${ }^{1+}$, Chukwuemeka A. Okolo ${ }^{1}$, Olachi Anuforom', Christopher Chime' ${ }^{1}$, Sam Peters ${ }^{1}$, Jibreel Jumare ${ }^{2}$, Obinna Ogbanufe ${ }^{3}$, Aliyu Ahmad ${ }^{1}$ and Nicaise Ndembi ${ }^{1,2}$

\begin{abstract}
Background: A negative status following confirmatory Early Infant Diagnosis (EID) is the desired pediatric outcome of prevention of Mother to Child Transmission (PMTCT) programs. EID impacts epidemic control by confirming noninfected HIV-exposed infants (HEIs) and prompting timely initiation of ART in HIV-infected babies which improves treatment outcomes.
\end{abstract}

Objectives: We explored factors associated with EID outcomes among HEl in North-Central Nigeria.

Method: This is a cross-sectional study using EID data of PMTCT-enrollees matched with results of HEl's dried blood samples (DBS), processed for DNA-PCR from January 2015 through July 2017. Statistical analyses were done using SPSS version 20.0 to generate frequencies and examine associations, including binomial logistic regression with $p<0.05$ being statistically significant.

Results: Of $14,448 \mathrm{HEl}$ in this analysis, $51.8 \%$ were female and $95 \%(n=12,801)$ were breastfed. The median age of the infants at sample collection was 8 weeks (IQR 6-20), compared to HEl tested after 20 weeks of age, those tested earlier had significantly greater odds of a negative HIV result ( $\leq 6$ weeks: $O R=3.8 ; 6-8$ weeks: $O R=2.1 ; 8-20$ weeks: $O R=1.5)$ with evidence of a significant linear trend $(p<0.001)$. Similarly, HEI whose mothers received combination antiretroviral therapy (CART) before $(\mathrm{OR}=11.8)$ or during the index pregnancy $(\mathrm{OR}=8.4)$ had significantly higher odds as compared to those whose mothers did not receive CART. In addition, HEl not breastfed had greater odds of negative HIV result as compared to those breastfed $(\mathrm{OR}=1.9)$.

Conclusions: CART prior to and during pregnancy, earlier age of HEl at EID testing and alternative feeding other than breastfeeding were associated with an increased likelihood of being HIV-negative on EID. Therefore, strategies to scale-up PMTCT services are needed to mitigate the burden of HIV among children.

\section{Introduction}

Early Infant Diagnosis (EID) that yields a negative result is a desired pediatric outcome of programs designed to prevent Mother to-Child Transmission (MTCT) of HIV [1]. For their HIV-infected mothers, staying alive and retained in care with good ART adherence and periodically demonstrated enduring suppression of HIV is the end goal [2]. MTCT in Nigeria accounts for majority of

\footnotetext{
*Correspondence: mtola@ihvnigeria.org

${ }^{\dagger}$ Patrick Dakum, Monday Tola and Nta Iboro contributed equally to this work

${ }^{1}$ Institute of Human Virology Nigeria, Federal Capital Territory, Abuja, Nigeria

Full list of author information is available at the end of the article
}

new HIV infections among children worldwide. Worldwide, with about 60,000 new cases reported annually from 2009 to 2012 [3]. In 2015, Nigeria alone was responsible for almost $30 \%$ of children newly infected with HIV globally ( $\mathrm{n}=41,000$ [4] of 150,000). Without antiretroviral therapy (ART), more than half of these children will die by 2 years of age [5].

Early Infant Diagnosis utilizes DNA-PCR to isolate viral nucleic acid in HIV-exposed infants (HEI) within 6 weeks of birth $[6,7]$ and up to 18 months of age [8] thus providing virological basis for entry into lifelong treatment for infected infants. EID impacts epidemic control by confirming non-infected HEIs and prompting timely initiation of ART in HIV-infected babies which improves 
treatment outcomes [9-11]. Furthermore, the quality of communication from care providers to parents/guardians [3] and the deployment of resources for follow-up of uninfected HEIs [4] are likely to be influenced by knowledge of an EID result.

Despite the importance of EID in mitigating MTCT, its implementation has been challenging in resource-limited settings [12-15], particularly in Nigeria, where only 6.3\% and 9\% of HEIs received EID in 2014 [16] and 2015 respectively, with only about $20 \%$ of those found to be eligible children actually receiving cART [17].

Evaluating current EID programs in relation to where implementation occurs is advocated [18] as this provides context-specific evidence to rethink and adapt current strategies [19]. This study presents data on the prevalence of HIV in HEI and explored the predictors of EID outcomes among HEI who received a DNA-PCR result in the high HIV prevalence settings North-Central Region of Nigeria.

\section{Material and methods Study design}

This was a cross-sectional retrospective design utilizing charts of initial DNA PCR testing at 12 weeks of age (or earliest opportunity thereafter) from HEI collected between January 2015 through July 2017.

\section{Study settings}

Institute of Human Virology, Nigeria (IHVN), supports 244 facilities in the Nigerian US President's Emergency
Plan for AIDS Relief (PEPFAR) program and all these sites send EID samples to a central molecular diagnostics laboratory for assays.

Nigeria's PEPFAR-supported EID program ride on a hub-spoke sample logistics arrangement, whereby peripheral health facilities (those lacking onsite PCR laboratory capacity) have samples collected, batched and delivered to specific public health laboratories for processing. Thereafter, results are dispatched back to these feeder sites (Fig. 1).

Nigeria is organized into six geopolitical zones (GPZ) of which North-Central (NC) including Abuja is one.

Each GPZ is comprised of adjacent states that share similar demography, cultural and political history. Nigeria's NC is considered her geospatial 'middle belt' and has a HIV prevalence rate (2014) of $3.4 \%$ similar to the national prevalence rate [20]. Study setting was a molecular diagnostics hub of the Asokoro Laboratory Training Centre (ALTC), located within Nigeria's Federal Capital Territory (FCT). The laboratory receives and processes dried blood spot (DBS) samples from the FCT and all the facilities in four of seven NC states (Benue, Nasarawa, Kogi and Niger) [21].

\section{Sample processing}

Dried DBS cards (from the facilities) were cut and $1100 \mu \mathrm{l}$ of specimen pre-extraction reagent (SPEX) was added. The samples were mixed using Eppendorf Thermomixer Comfort (manufactured by Eppendorf AG, Hamburg, Germany) at $56{ }^{\circ} \mathrm{C}$ for $10 \mathrm{~min}$ at $1000 \mathrm{rpm}$

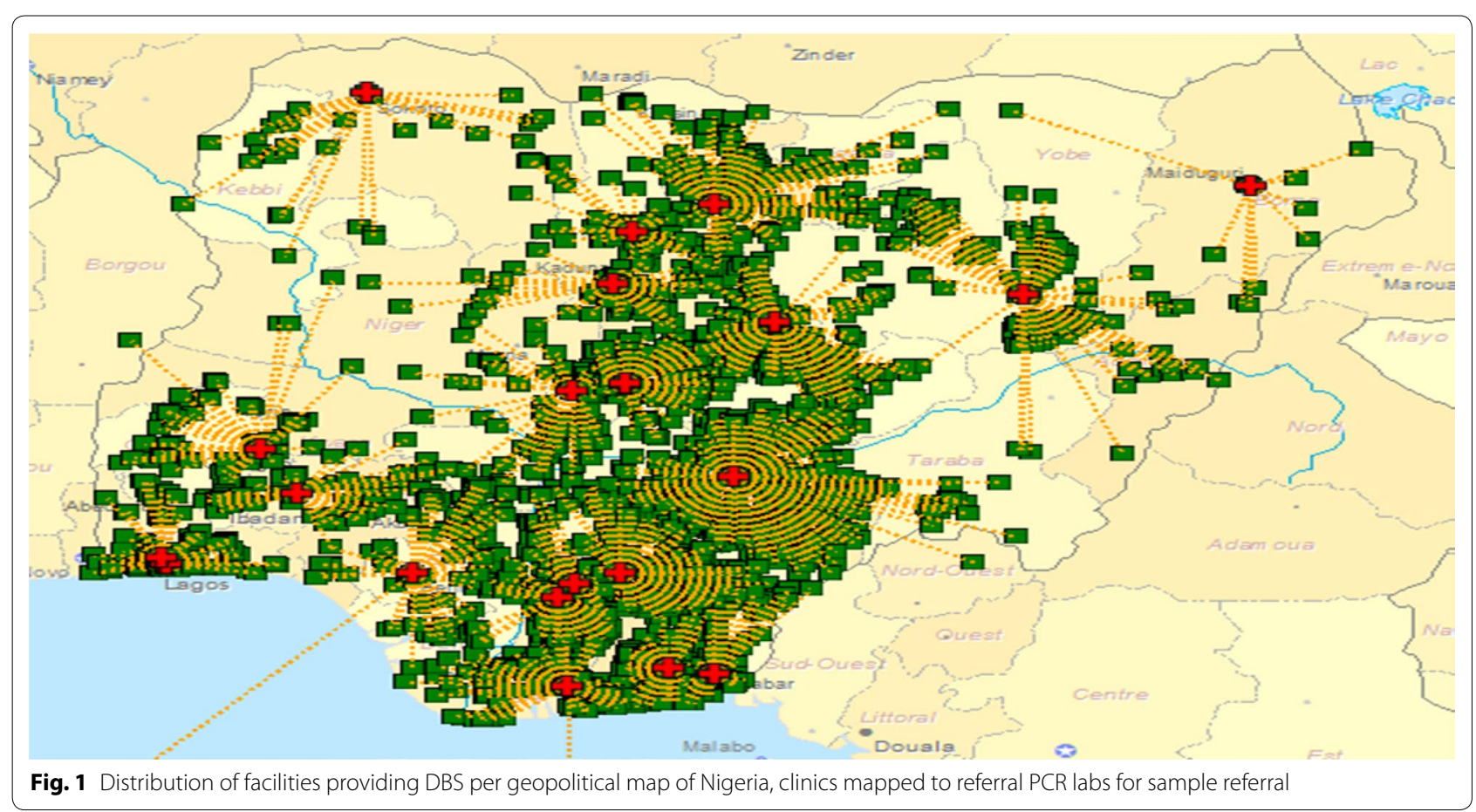


[17]. Known positive and negative controls were included in each run as per the Manufacturer's instructions. The samples and controls were then placed in racks and transferred to the Cobas ${ }^{\circledR}$ Ampliprep (CAP) (manufactured by Roche, Mannheim, Germany) where DNA extraction took place for $90 \mathrm{~min}$. Using real-time polymerase chain reaction (PCR), amplification and detection in Cobas ${ }^{\circledR}$ Taqman $^{\circledR}$ (CTM) (manufactured by Roche, Mannheim, Germany) then followed for $3 \mathrm{~h}$ $30 \mathrm{~min}$. For positive samples, a repeat assay was carried out. The DBS data processing was done using the Amplilink software version 3.3 [17].

\section{Data source}

De-identified data was retrieved from the laboratory's Information Management System (LIMS) via export. Information for each data point included: (1) Site Identification number; (2) Date of collection; (3) Location of site by state; (4) Date specimen was received at the processing laboratory; (5) Date of assay (6) Result of Test; (7) Date of dispatch of result; (8) Infant's age; (9) Infants sex; (10) ART administered to mother; and (11) Breastfeeding status of HEI children.

\section{Data analysis}

Relevant data were cleaned, coded and exported into SPSS version 20.0 (SPSS 2011 IBM Corp, New York, United States) for statistical analysis. We described frequencies, compared associations and performed a binomial logistic regression to ascertain the effects of several factors on the likelihood of infants achieving a negative HIV DNA-1 PCR result. In the model, independent variables explored are sex of HEI (male/female), breastfeeding status (yes/no) and treatment administered to mother: prophylaxis, combination anti-retroviral treatment (cART) during, or cART before index pregnancy. A Cochran-Armitage test of trend was used to see if a linear relationship exists between the time of collection of a DBS sample and the proportion of HEI samples that returned a HIV-positive DNA-PCR result.

\section{Results}

A total of 14,488 DBS sample were analyzed, of which 13,738 (94.8\%) returned negative results for HIV DNAPCR. Median and mean age of HEI at first sample collection $(\mathrm{n}=13,646)$ was 8 weeks (IQR $6-20)$ and 14.64 weeks $(\mathrm{SD}=14.98 ; 95 \% \mathrm{CI} 0-260)$ respectively as shown in Table 1.

About $41.4 \%$ of HEIs had DBS drawn up to 6 weeks, $16.3 \%$ between 6 and 8 weeks and 36.5\% after 8 weeks. $42.7 \%(n=6192)$ of assayed samples were drawn from female HEI and $88.4 \%(n=12,801)$ of HEI were breastfed (Table 1). Most HIV positive women received
Table 1 Baseline characteristics of mother-HEI pair

\begin{tabular}{|c|c|c|}
\hline Characteristic & Frequency & $\begin{array}{l}\text { Percentage } \\
\text { (\%) }\end{array}$ \\
\hline $\begin{array}{l}\text { Age (in weeks) of HIV Exposed } \\
\text { Infant (HEI) at first dried blood } \\
\text { spot collection (DBS): median } \\
\text { (IQR) }\end{array}$ & $8.00(6-20)$ & \\
\hline$\leq 6$ weeks & 6000 & 41.4 \\
\hline $6.1-8$ weeks & 2358 & 16.3 \\
\hline $8.1-20$ weeks & 2309 & 15.9 \\
\hline $20.1+$ weeks & 2979 & 20.6 \\
\hline Missing & 842 & 5.8 \\
\hline \multicolumn{3}{|l|}{ Sex of HEl } \\
\hline Male & 6648 & 45.9 \\
\hline Female & 6192 & 42.7 \\
\hline Missing & 1648 & 11.4 \\
\hline \multicolumn{3}{|l|}{ Breastfeeding status of $\mathrm{HEl}$} \\
\hline Yes & 12,801 & 88.4 \\
\hline No & 617 & 4.2 \\
\hline Missing & 1070 & 7.4 \\
\hline \multicolumn{3}{|c|}{ Therapy received by pregnant HIV-infected mother } \\
\hline No Rx & 1010 & 7 \\
\hline Prophylaxis & 159 & 1.1 \\
\hline CART before pregnancy & 7903 & 54.5 \\
\hline CART during index pregnancy ${ }^{a}$ & 3651 & 25.2 \\
\hline Missing & 1765 & 12.2 \\
\hline \multicolumn{3}{|l|}{ DNA-PCR result of first DBS } \\
\hline Negative & 13,738 & 94.8 \\
\hline Positive & 750 & 5.2 \\
\hline
\end{tabular}

a Index refers to pregnancy that produced HEl at time of this study

combination ART (cART) before the index pregnancy (54.5\%, $\mathrm{n}=7903), 25.2 \%(\mathrm{n}=3651)$ had cART for the first time during the index pregnancy, those who received prophylaxis during labor were $1.1 \%(n=159)$ while $7.0 \%$ $(\mathrm{n}=1010)$ received no ART (Table 1$)$.

\section{Tests of linear relationship}

Time of sample collection was at $<6$ weeks $(n=6000)$, 6.1-8 weeks $(n=2358), 8.1-20$ weeks $(n=2309)$, above 20 weeks $(\mathrm{n}=2979)$, and the proportion of positive results returned was $1.9 \%, 4.0 \%, 7.1 \%$ and $11.4 \%$ respectively. The Cochran-Armitage test of trend showed a statistically significant linear trend, $\mathrm{p}<0.001$, with longer time of collection of DBS associated with a higher proportion of positive DNA-PCR results (Table 2).

\section{Association of maternal and infant characteristics with EID outcome}

To ascertain the associations that age at DBS collection, sex of HEI, breastfeeding status, maternal treatment regimen: prophylaxis, combination anti-retroviral treatment (cART) during, or before index pregnancy had on the 
Table 2 Cross tabulation between age of infant at DBS collection, maternal treatment status and DNA PCR result

\begin{tabular}{|c|c|c|c|c|}
\hline \multirow[t]{2}{*}{ Characteristic } & \multirow[t]{2}{*}{ Frequency } & \multicolumn{2}{|c|}{ DNA_PCR of HEI } & \multirow[t]{2}{*}{$p$-value } \\
\hline & & Positive (\%) & Negative (\%) & \\
\hline \multicolumn{4}{|c|}{$\begin{array}{l}\text { Age of HIV exposed infant (HEI) at first dried blood spot collec- } \\
\text { tion (DBS) }\end{array}$} & $<0.01$ \\
\hline$\leq 6$ weeks & 6000 & $116(1.9)$ & $5884(98.1)$ & \\
\hline $6.1-8$ weeks & 2358 & $94(4)$ & $2264(96)$ & \\
\hline 8.1-20 weeks & 2309 & $164(7.1)$ & $2145(92.9)$ & \\
\hline $20.1+$ weeks & 2979 & $340(11.4)$ & 2639 (88.6) & \\
\hline Total & 13,646 & $714(5.2)$ & $12,932(94.8)$ & \\
\hline \multicolumn{4}{|c|}{ Maternal treatment status } & $<0.01$ \\
\hline CART & 13,478 & $446(3.3)$ & $13,032(96.7)$ & \\
\hline $\begin{array}{l}\text { Without medica- } \\
\text { tion }\end{array}$ & 1010 & $304(30.1)$ & $706(69.9)$ & \\
\hline Total & 14,488 & $750(5.2)$ & $13,738(94.8)$ & \\
\hline
\end{tabular}

likelihood of achieving a negative HIV DNA-PCR result following EID, a predictive model (binomial logistic regression) was performed.

The full model containing all predictors was statistically significant $\mathrm{p}<0.001$, indicating ability to differentiate those with successful and failed EID outcomes. The model explained between $7.3 \%$ of the variance in EID outcomes and correctly classified $94.9 \%$ of the cases. 5 variables were statistically significant; breast feeding status of HEI at DBS, age at DBS collection, age of HEI at DBS collection, maternal cART during pregnancy and cART before pregnancy. Controlling for other factors in the model, HEI age at DBS collection of less than or equal to 6 weeks were 4 (3.813) more likely to have HIV negative results when compared to those who had DBS at greater than 20 weeks. Similarly, odds of achieving a negative DNA-PCR result was 2 (2.087) and 1.5 (1.449) for DBS collection at ages 6.1 to 8 weeks and 8.1 to 20 weeks respectively compared to DBS collection at above HEI age above 20 weeks.

cART before pregnancy and during pregnancy were 12 $(\mathrm{OR}=11.79)$ and $8(\mathrm{OR}=8.349)$ times more likely respectively, to have HIV negative infants compared to no treatment (see Table 3). Mothers given a prophylaxis regimen during labour had four-fold odds of an infant who returned a negative DNA-PCR result than mothers who received no therapy. Those who did not breastfeed babies at time of DBS had twice the odds of their HEI achieving a negative DNA-PCR result compared to those who breastfed.

\section{Discussion}

Our study shows that factors like breastfeeding, maternal treatment status (cART or no ART) and age when HEI DBS, can predict the achievement of a negative DNAPCR result following EID in the High HIV-prevalence settings of North-central Nigeria.

In this study, median age of HEIs at first DBS collection was approximately 8 weeks with only $44 \%$ of infants DBS samples taken below 6 weeks of age thereby predisposing the children to a delay in ART initiation for confirmed cases. A longer time of DBS collection and in-effect EID predicted likelihood of HEI being HIV+. For later presentation, it is plausible that symptomatic manifestation of immunologic decline in HIV infection may have

Table 3 Logistic regression predicting likelihood of negative DNA-PCR based on gender, age at DBS collection, breastfeeding and maternal treatment regimen

\begin{tabular}{|c|c|c|c|c|c|}
\hline Characteristics & $\begin{array}{l}\text { EID-HIV negative 1st DNA PCR } \\
(\mathrm{N}=13,738)\end{array}$ & OR & $95 \% \mathrm{Cl}$ & & p value \\
\hline Breastfeeding $^{\text {a }}$ & 12,801 & 1.94 & 1.12 & 3.35 & 0.018 \\
\hline \multicolumn{6}{|l|}{ Maternal treatment } \\
\hline No maternal treatment & 1010 & 1 & & & 0.000 \\
\hline Prophylaxis & 159 & 4.27 & 2.12 & 8.62 & 0.000 \\
\hline CART before pregnancy & 7903 & 11.79 & 9.41 & 14.78 & 0.000 \\
\hline CART during pregnancy & 3651 & 8.35 & 6.52 & 10.69 & 0.000 \\
\hline \multicolumn{6}{|l|}{ Age at DBS collection, week } \\
\hline HEl age at DBS > 20 & 2979 & 1 & & & 0.000 \\
\hline HEl age at $\mathrm{DBS} \leq 6$ & 6000 & 3.81 & 2.91 & 4.99 & 0.000 \\
\hline $\mathrm{HEl}$ age at $\mathrm{DBS}=6.1-8$ & 2358 & 2.09 & 1.57 & 2.78 & 0.000 \\
\hline $\mathrm{HEl}$ age at $\mathrm{DBS}=8.1-20$ & 2309 & 1.45 & 1.14 & 1.84 & 0.003 \\
\hline \multicolumn{6}{|l|}{ Infant sex $(n)^{b} \%$} \\
\hline Female & $6192(42.7)$ & 0.98 & 0.81 & 1.18 & 0.804 \\
\hline Missing & $1648(11.4 \%)$ & & & & \\
\hline
\end{tabular}

\footnotetext{
a Not breastfed compared to breastfed
}

${ }^{b}$ Female HEl compared to males 
prompted mothers/guardians to seek health facility and opportune HEI to EID. A study in Kenya showed that information passed to mother during pregnancy, mothers higher formal education and low experience of stigma could predict on-time (infant $\leq 6$ weeks of age) EID [17].

Survival gains of commencing early infant antiretroviral therapy declines when diagnosis is late [22-24] with rapid disease progression and mortality [25] in early life. Timely definitive diagnosis is critical in allowing early initiation of life-saving ART [26] as demonstrated in the children with HIV early antiretroviral (CHER) study [27], which reported a $76 \%$ and $75 \%$ aversion of early infant mortality and HIV progression respectively [28]. Performance of Nigeria's EID logistics is affecting EID outcomes.

Breastfeeding is important for child survival $[29,30]$ and consistent with other studies in Nigeria [28, 31], was common among study mother-HEI pairs $88.9 \%$ $(\mathrm{n}=3232)$. Mothers living with HIV, especially in LMIC, should breastfeed for 12 months and may continue breastfeeding for up to 24 months or longer, while being fully supported for ART adherence [32]. This is to help fight against malnutrition and death resulting from cholera due to poor hygiene. Breastfeeding should only stop once a nutritionally adequate and safe diet without breast milk can be provided [32]. Breastfeeding by HIV positive mothers was a significant predictor of HEI outcome in this study and is linked to continuing risk of postnatal infection [33], with documented MTCT rate of 13\% at six weeks rising to $23 \%$ at the end of breastfeeding [34]. Data on type (exclusive or mixed), duration [35] and frequency of breastfeeding, mother's immunological staging (HIV viral load/CD4+) and HEI testing after a 6-week window period following stop of breastfeeding [12] is required to further investigate this and is recommended.

Majority (54.5\%) of HIV positive mothers were already on cART before the index pregnancy, whilst almost a third received cART for the first time. Maternal prophylaxis and cART were significant predictors of EID outcomes. Exponential rises in the chance of achieving a negative DNA-PCR result for HEI was related to the timing of cART with best results if mother started cART prior to pregnancy. This finding stands unadjusted for Mother's cART adherence, duration of therapy or immunological status, and for the method of delivery (vaginal or operative) or timing of EID testing. It is thus deduced that aside these and other factors, substantial programwide benefit of averting MTCT is achieved if cART for mother is ensured.

This speaks to the present MTCT issue in Nigeria where only $29 \%$ of HIV-positive pregnant women received ART [36] in 2014. Hence, as a strategy to mitigate the growing population of the 380,000 HIVpositive children residing in-country [20,37], prevention of MTCT and EID programs in Nigeria need to urgently scale-up ART coverage for HIV infected females of reproductive age and mothers.

Nigeria adopted the WHO 'Test and Treat' policy in June 2016 [38] to accelerate early and universal placement on ART for all HIV positive persons [2]. In prevention of MTCT this translates to starting HIV positive pregnant women early on lifelong cART irrespective of clinical or immunological criteria (option $\mathrm{B}+$ ) [39]. The difference in odds between the earlier placement of HIV positive mothers (previous vs index pregnancy) supports the notion that optimization of favorable pediatric outcomes is achieved at earliest cART initiation of all peripartum HIV-infected women [40].

\section{Limitations}

This study was limited by the extent of variables utilized, due to non-availability of others such as baseline maternal viral load or clinical staging and follow-up HEI testing on cessation of breastfeeding. This limited our ability to explore the role of other characteristics that may be linked to EID outcomes, in addition to possible incomplete control of confounding for the associations explored. Another limitation is potential selection bias due to low EID rates among PMTCT clients which may affect generalizability of the findings. Another major challenge is the issue of missing data as request forms from the clinics are not completely filled. Clinicians needs to be aware of the importance of properly filling request forms, to enable us have a good picture of the program during evaluation.

\section{Conclusion}

This study showed that provision of cART for HIV infected mothers prior to and during pregnancy is associated with an increased likelihood of achieving a negative EID result. Overall program wide benefit can be optimized if lifelong cART coverage is increased for HIV positive pregnant women.

\footnotetext{
Acknowledgements

The authors thank the study participants who agreed to implementation.

Authors' contributions

PD coordinated the study. PD, MT, NI, CAO, OA, CC, SP, JJ, OO, AA, and NN conceived design, provided interpretation of the data and critical review, and revision of the manuscript. MT, and OA performed laboratory analysis and interpretation of laboratory data. All authors read and approved the final manuscript.

Funding

The authors were supported by funding from the PEPFAR Program.
} 


\section{Availability of data and materials}

The datasets during and/or analyzed during the current study available from the corresponding author on reasonable request.

\section{Ethics approval and consent to participate}

The study utilized secondary data analysis from the laboratory database of the National HIV program which has approval from the Nigerian National Health Research Ethics Committee (NHREC Approval \#NHREC/01/01/2007-14/08/2017).

\section{Consent for publication}

Not applicable.

\section{Competing interests}

The authors declare that they have no competing interests.

\section{Author details}

${ }^{1}$ Institute of Human Virology Nigeria, Federal Capital Territory, Abuja, Nigeria. ${ }^{2}$ Institute of Human Virology, University of Maryland School of Medicine, Baltimore, MD, USA. ${ }^{3}$ U.S. Centers for Disease Control and Prevention, Federal Capital Territory, Abuja, Nigeria.

Received: 27 March 2019 Accepted: 30 August 2019

Published online: 14 September 2019

\section{References}

1. Cooper ER, Charurat M, Mofenson L, Hanson IC, Pitt J, Diaz C, Hayani K, Handelsman E, Smeriglio V, Hoff R, Blattner W, Women and Infants' Transmission Study Group. Combination antiretroviral strategies for the treatment of pregnant HIV-1-infected women and prevention of perinatal HIV-1 transmission. J Acquir Immune Defic Syndr. 2002;29:484-94.

2. FMOH. National Guidelines for HIV Prevention Treatment and Care, Abuja. 2016.

3. UNAIDS. Countdown to zero: global plan towards the elimination of New HIV infections among children by 2015 and keeping their mothers alive. Geneva. 2011. https://dx.doi.org/ISBN:\%20978-92-9173-897-7.

4. Sam-Agudu NA, Ramadhani HO, Isah C, Erekaha S, Fan-Osuala C, Anaba $U$, Adejuyigbe EA, Charurat M. The impact of structured mentor mother programs on presentation for early infant diagnosis testing in rural northcentral Nigeria: a prospective paired cohort study. J Acquir Immune Defic Syndr. 2017;75:S182-S189189.

5. Newell M-L, Coovadia H, Cortina-Borja M, Rollins N, Gaillard P, Dabis F. Mortality of infected and uninfected infants born to HIV-infected mothers in Africa: a pooled analysis. Lancet. 2017;364:1236-43. https://doi. org/10.1016/S0140-6736(04)17140-7.

6. Lilian RR, Kalk E, Bhowan K, Berrie L, Carmona S, Technau K, Sherman GG. Early diagnosis of in utero and intrapartum HIV infection in infants prior to 6 weeks of age. J Clin Microbiol. 2012;50:2373-7. https://doi. org/10.1128/JCM.00431-12.

7. Sherman GG, Cooper PA, Coovadia AH, Puren AJ, Jones SA, Mokhachane $\mathrm{M}$, Bolton KD. Polymerase chain reaction for diagnosis of human immunodeficiency virus infection in infancy in low resource settings. Pediatr Infect Dis J. 2005;24:993-7.

8. WHO. ANNEX 1: summary of findings and quality of evidence evaluation for the use of virological testing. In: WHO Recomm. diagnosis HIV infect. infants child. Geneva: World Health Organization; 2010.

9. Violari A, Cotton MF, Gibb DM, Babiker AG, Steyn J, Madhi SA, JeanPhilippe P, McIntyre JA, CHER Study Team. Early antiretroviral therapy and mortality among HIV-infected infants. N Engl J Med. 2008;359:2233-44. https://doi.org/10.1056/NEJMoa0800971.

10. Cotton MF, Violari A, Otwombe K, Panchia R, Dobbels E, Rabie H, Josipovic D, Liberty A, Lazarus E, Innes S, van Rensburg AJ, Pelser W, Truter H, Madhi SA, Handelsman E, Jean-Philippe P, McIntyre JA, Gibb DM, Babiker AG. Early time-limited antiretroviral therapy versus deferred therapy in South African infants infected with HIV: results from the children with HIV early antiretroviral (CHER) randomised trial. Lancet. 2016;382:1555-633. https:// doi.org/10.1016/S0140-6736(13)61409-9.

11. Laughton B, Cornell M, Grove D, Kidd M, Springer PE, Dobbels E, van Rensburg AJ, Violari A, Babiker AG, Madhi SA, Jean-Philippe P, Gibb DM,
Cotton MF. Early antiretroviral therapy improves neurodevelopmental outcomes in infants. AIDS. 2012;26:1685-90. https://doi.org/10.1097/ QAD.0b013e328355d0ce.

12. WHO. Antiretroviral therapy for HIV infection in infants and children: towards universal access: recommendations for a public health approach: 2010 Revision. Geneva: World Health Organization; 2010.

13. Ubesie AC. Pediatric HIV/AIDS in sub-Saharan Africa: emerging issues and way forward. Afr Health Sci. 2012;12:297-304.

14. Ciaranello AL, Park J-E, Ramirez-Avila L, Freedberg KA, Walensky RP, Leroy V. Early infant HIV-1 diagnosis programs in resource-limited settings: opportunities for improved outcomes and more cost-effective interventions. BMC Med. 2011;9:59. https://doi.org/10.1186/1741-7015-9-59.

15. World Health Organization. Scaling up priority HIV/AIDS interventions in the health sector: Progress Report. Geneva: World Health Organization; 2010.

16. Pharr JR, Obiefune MC, Ezeanolue CO, Osuji A, Ogidi AG, Gbadamosi S, Patel D, Iwelunmor J, Yang W, Ogedegbe G, Ehiri JE, Sam-Agudu NA, Ezeanolue EE. Linkage to care, early infant diagnosis, and perinatal transmission among infants born to HIV-infected Nigerian mothers: evidence from the healthy beginning initiative. J Acquir Immune Defic Syndr. 2016;72(Suppl 2):S154-S160160. https://doi.org/10.1097/QAl.0000000000 001051 .

17. Govender K, Parboosing R, Siyaca N, Moodley P. Dried blood spot specimen quality and validation of a new pre-analytical processing method for qualitative HIV-1 PCR, KwaZulu-Natal, South Africa. Afr J Lab Med. 2016;5:349. https://doi.org/10.4102/ajlm.v5i1.349.

18. Cook RE, Ciampa PJ, Sidat M, Blevins M, Burlison J, Davidson MA, Arroz $J A$, Vergara AE, Vermund SH, Moon TD. Predictors of successful early infant diagnosis of HIV in a rural district hospital in Zambézia, Mozambique. J Acquir Immune Defic Syndr. 2011;56:e104-e109109. https://doi. org/10.1097/QAl.0b013e318207a535.

19. UNAIDS. UNAIDS briefing book. Geneva; 2016.

20. NACA, UNAIDS. Global AIDS Response Progress Report: Nigeria, Abuja. 2014

21. Mei JV, Alexander JR, Adam BW, Hannon WH. Use of filter paper for the collection and analysis of human whole blood specimens. J Nutr. 1636S;131:1631S-6S.

22. Wamalwa D, Benki-Nugent S, Langat A, Tapia K, Ngugi E, Slyker JA, Richardson BA, John-Stewart GC. Survival benefit of early infant antiretroviral therapy is compromised when diagnosis is delayed. Pediatr Infect Dis J. 2012;31:729-31. https://doi.org/10.1097/INF.0b013e3182587796.

23. Leyenaar JK, Novosad PM, Ferrer KT, Thahane LK, Mohapi EQ, Schutze GE, Kline MW. Early clinical outcomes in children enrolled in human immunodeficiency virus infection care and treatment in Lesotho. Pediatr Infect Dis J. 2009;29:1. https://doi.org/10.1097/INF.0b013e3181bf8ecb.

24. Mphatswe W, Blanckenberg N, Tudor-Williams G, Prendergast A, Thobakgale C, Mkhwanazi N, McCarthy N, Walker BD, Kiepiela P, Goulder P. High frequency of rapid immunological progression in African infants infected in the era of perinatal HIV prophylaxis. AIDS. 2007;21:1253-61. https://doi. org/10.1097/QAD.0b013e3281a3bec2.

25. KIDS-ART-LINC Collaboration Low risk of death, but substantial program attrition, in pediatric hiv treatment cohorts in Sub-Saharan Africa. J Acquir Immune Defic Syndr. 2008;49:523-31. https://doi.org/10.1097/QAl.0b013 e31818aadce.

26. Prendergast AJ, Penazzato $M$, Cotton M, Musoke P, Mulenga V, Abrams EJ, Gibb DM. Treatment of young children with hiv infection: using evidence to inform policymakers. PLoS Med. 2012;9:e1001273. https://doi. org/10.1371/journal.pmed.1001273.

27. Cotton MF, Violari A, Otwombe K, Panchia R, Dobbels E, Rabie H, Josipovic D, Liberty A, Lazarus E, Innes S, van Rensburg AJ, Pelser W, Truter H, Madhi SA, Handelsman E, Jean-Philippe P, McIntyre JA, Gibb DM, Babiker AG, CHER study team. Early time-limited antiretroviral therapy versus deferred therapy in South African infants infected with HIV: results from the children with HIV early antiretroviral (CHER) randomised trial. Lancet. 2013;382:1555-633. https://doi.org/10.1016/S0140-6736(13)61409-9.

28. Anoje C, Aiyenigba B, Suzuki C, Badru T, Akpoigbe K, Odo M. Reducing mother-to-child transmission of HIV: findings from an early infant diagnosis program in south-south region of Nigeria. BMC Public Health. 2012;12:184. https://doi.org/10.1186/1471-2458-12-184.

29. Effect of breastfeeding on infant and child mortality due to infectious diseases in less developed countries: a pooled analysis. WHO Collaborative 
Study Team on the role of breastfeeding on the prevention of infant mortality. Lancet. 2000; 355:451-5. https://www.ncbi.n/m.nih.gov/pubme d/10841125. Accessed 6 Nov 2017).

30. Coovadia H, Kindra G. Breastfeeding to prevent HIV transmission in infants: balancing pros and cons. Curr Opin Infect Dis. 2008;21:11-5. https ://doi.org/10.1097/QCO.0b013e3282f40689.

31. Lawani L, Onyebuchi A, lyoke C, Onoh R, Nkwo P. The challenges of adherence to infant feeding choices in prevention of mother-to-child transmission of HIV infections in South East Nigeria. Patient Prefer Adherence. 2014;8:377. https://doi.org/10.2147/PPA.S61796.

32. 2016 WHO. Updates on HIV and infant feeding guideline. 2016; 68 .

33. Fowler MG, Coovadia H, Herron CM, Maldonado Y, Chipato T, Moodley D, Musoke P, Aizire J, Manji K, Stranix-Chibanda L, Fawzi W, Chetty V, Msweli L, Kisenge R, Brown E, Mwatha A, Eshleman SH, Richardson P, Allen M, George K, Andrew P, Zwerski S, Mofenson LM, Jackson JB, HPTN 046 Protocol Team. Efficacy and safety of an extended nevirapine regimen in infants of breastfeeding mothers with HIV-1 infection for prevention of HIV-1 transmission (HPTN 046). J Acquir Immune Defic Syndr. 2014;65:366-74. https://doi.org/10.1097/QAl.0000000000000052.

34. UNAIDS. Global plan: Country Fact Sheet_Nigeria. Geneva; 2016.

35. Datta P, Embree JE, Kreiss JK, Ndinya-Achola JO, Braddick M, Temmerman M, Nagelkerke NJ, Maitha G, Holmes KK, Piot P. Mother-to-child transmission of human immunodeficiency virus type 1: report from the Nairobi Study. J Infect Dis. 1994;170:1134-40.

36. NACA. Global AIDS Response Country Progress Report: Nigeria, Abuja. 2015.

37. UNAIDS. Nigeria: HIV and AIDS estimates. Geneva; 2013.

38. WHO. Nigeria aligns national protocol to WHO'Treat All' guidelines on HIV/AIDS prevention and treatment, Abuja. 2016.

39. Use of AntiretrovirAl DrUgs for treAting PregnAnt Women AnD Preventing Hiv infection in infAnts EXECUTIVE SUMMARY. 2012. https://www. who.int/hiv/PMTCT_update.pdf. Accessed 6 Nov 2017.

40. Zolfo M, De Weggheleire A, Schouten E, Lynen L. Time for "test and treat" in prevention of mother-to-child transmission programs in low- and middle-income countries. J Acquir Immune Defic Syndr. 2010;55:287-9. https://doi.org/10.1097/QAl.0b013e3181eef3da.

\section{Publisher's Note}

Springer Nature remains neutral with regard to jurisdictional claims in published maps and institutional affiliations.
Ready to submit your research? Choose BMC and benefit from:

- fast, convenient online submission

- thorough peer review by experienced researchers in your field

- rapid publication on acceptance

- support for research data, including large and complex data types

- gold Open Access which fosters wider collaboration and increased citations

- maximum visibility for your research: over $100 \mathrm{M}$ website views per year

At BMC, research is always in progress.

Learn more biomedcentral.com/submissions 